\title{
Performance of Palm Oil Clinker as a Bio-Filler with Hybrid Fillers in Intumescent Fire Protective Coatings for Steel
}

(Prestasi Arang Kelapa Sawit sebagai Pengisi Biologi dengan Pengisi Hibrid di dalam Lapisan Penahan Api untuk Keluli)

\section{S.A.S. MUSTAPA \& N.H. RAMLi SULONG*}

\begin{abstract}
Intumescent coatings are an effective method for fire protection of steel structures. The search for more environmental friendly intumescent coatings has led to the utilization of palm oil clinker (POC) as a bio-filler in solvent-borne intumescent coatings in order to improve fire protection performance, mechanical strength and water resistance of steel structures. In this research, POC and hybrid fillers are mixed with an acrylic binder and then blended with flame-retardant additives in order to produce intumescent coatings. The samples were tested using Bunsen burner test, thermogravimetry analysis, surface spread of flame test, field emission scanning electron microscopy, static immersion test, and adhesion strength test. It was found that the optimum composition of POC and hybrid fillers gives the best fire protection performance with the lowest equilibrium temperature $\left(171.3^{\circ} \mathrm{C}\right)$, high thermal stability, good water resistance and excellent mechanical properties. The results of the surface spread of flame test show that Sample A3, A4, and A6 were classified as Class 1, which is the best classification. For Sample A6 (a hybrid formulation), the addition of aluminium hydroxide gives better water resistance with the lowest rate of weight change $(<0.2 \%)$, while the addition of magnesium hydroxide enhances the bonding strength of the coating up to $125 \%$ compared with Sample Al which only has a single filler POC. It can be concluded that the optimum composition of $P O C$ and hybrid fillers results in intumescent coating with the greatest fire protection performance.
\end{abstract}

Keywords: Fire protection; hybrid fillers; intumescent coatings; palm oil clinker; solvent-borne

ABSTRAK

Lapisan penahan api merupakan kaedah yang berkesan dalam perlindungan api bagi struktur keluli. Pencarian lapisan penahan api yang lebih mesra alam telah membawa kepada penggunaan arang kelapa sawit (POC) sebagai bahan pengisi biologi di dalam lapisan penahan api berasaskan pelarut bagi meningkatkan kadar kecekapan perlindungan api, kekuatan mekanik dan daya ketahanan terhadap air pada struktur keluli. Dalam kajian ini, PoC dan bahan pengisi hibrid dirumuskan bersama bahan pengikat akrilik dan dicampurkan dengan bahan tambahan tertentu untuk menghasilkan lapisan penahan api. Seтua sampel diuji dengan menggunakan ujian penunu Bunsen, analisis termogravimetri, ujian penyebaran api, mikroskopi elektron imbasan pancaran medan, daya tahan air dan daya lekatan. Didapati bahawa penggunaan optimum POC bersama bahan pengisi hibrid menunjukkan kecekapan perlindungan api terbaik dengan suhu keseimbangan terendah $\left(171.3^{\circ} \mathrm{C}\right)$, kestabilan haba yang tinggi, daya ketahanan terhadap air dan kekuatan mekanik yang bagus. Ujian penyebaran api menunjukkan Sampel A3, A4 dan A6 berada di Kelas 1 iaitu kelas terbaik. Bagi Sampel A6 (rumusan dengan bahan pengisi hibrid), penambahan aluminium hidroksida meningkatkan ketahanan terhadap air dengan menunjukkan kadar perubahan berat yang paling rendah $(<0.2 \%)$, manakala penambahan magnesium hidroksida meningkatkan daya lekatan lapisan penahan api sehingga 125\% berbanding dengan Sampel A1 yang mempunyai bahan pengisi tunggal POC. Kesimpulannya, komposisi optimum POC dan bahan pengisi hibrid memberikan kesan yang terbaik dalam kecekapan perlindungan api bagi lapisan penahan api.

Kata kunci: Arang kelapa sawit; bahan pengikat pelarut; bahan pengisi hibrid; lapisan penahan api; perlindungan api

\section{INTRODUCTION}

Intumescent coatings have become one of the most popular passive fire protection materials to protect steel structures from fire in industrial and commercial buildings owing to the effectiveness of these coatings (Liang et al. 2013). Intumescent coatings are applied onto the steel structures for fire protection, which will prevent the building from collapsing in the event of a fire. This can save thousands of precious lives since the building structure is retained for a longer period, providing ample time for people to evacuate the building. Steel begins to lose its structural properties upon reaching a temperature of $550^{\circ} \mathrm{C}$, which leads to a rapid loss in strength and stiffness and eventually causes the steel structure to collapse (Dai et al. 2009; Norgaard et al. 2013). When exposed to a sufficiently high temperature, intumescent coatings form a porous char that thermally insulates the steel substrate from heat and prevent the substrate from 
reaching the critical temperature (Duquesne et al. 2004; Jimenez et al. 2006a). In general, three flame-retardant additives were used in formulation of intumescent coatings: An acid source (ammonium polyphosphate, APP); a carbon source (pentaerythritol, PER); and a blowing agent (melamine, MEL). These flame-retardant additives are blended with flame-retardant fillers and a binder. The binder is an essential component of intumescent coating formulations since it contributes to the formation and expansion of a carbonaceous structure that protects the steel from heat transfer (Duquesne et al. 2005; Jimenez et al. 2006b; Price et al. 2002). To date, metal hydroxides are the most commonly used flame-retardant fillers. As the temperature rises, these inorganic fillers decompose endothermically and absorb energy. The fillers release non-flammable molecules (water and/or carbon dioxide) which dilute combustible gases and promote the formation of a protective ceramic or vitreous layer (Yew 2011).

The use of intumescent coatings as a passive means of fire protection is one of the easiest ways to prevent fire from penetrating through the steel substrate. However, this technique is not commonly implemented because of the high production cost of intumescent coatings associated with the costly synthetic fillers. Furthermore, the use of other bio-fillers such as chicken eggshells (Yew et al. 2013) is cumbersome since the eggshells need to be processed in order to attain the appropriate particle size before the eggshells can be used as filler. In this research, POC is used as a bio-filler in order to reduce the use of synthetic fillers. In addition, it is more economical and practical to use POC since POC can be used directly from the source without going through any additional processing. Moreover, POC is available in bulk quantities.

One of the prevailing problems in Malaysia nowadays is managing by-product wastes generated from palm oil processing since Malaysia is the second largest producer of palm oil in the world (Ahmmad et al. 2016). POC is one of the by-products of the palm oil industry, which is produced in large quantities and treated as wastes. POC is produced as a result of incinerating oil palm shells and palm oil fibres (30:70 ratio) at $850^{\circ} \mathrm{C}$ in order to generate power for plant operations (Jumaat et al. 2015). Using POC as a bio-filler in intumescent coatings is an alternative technique which will reduce production cost and more importantly, these wastes are reused rather than being disposed into the landfill.
Many researchers have studied the performance of intumescent coatings in terms of fire retardancy, mechanical strength and water resistance (Bodzay et al. 2011; Enescu et al. 2013; Pan et al. 2012; Wang \& Yang 2010; Yew \& Sulong 2012). The objective of this research was to develop the best formulation for intumescent coating using hybrid fire-retardant fillers, in which POC bio-filler is one of the key components. The intumescent coatings are applied onto steel test specimens and the performance of these coatings is assessed.

\section{MATERIALS AND METHODS}

The first part of this research was to investigate the thermal stability of the POC using thermogravimetric analysis (TGA). The intumescent coatings were prepared by mixing three flame-retardant additives: APP, PER and MEL at a ratio of 2:1:1. The flame-retardant additives were blended with 53 wt. \% of acrylic binder. Next, the mixture was blended with four types of fire-retardant fillers: POC bio-filler, magnesium hydroxide $\left[\mathrm{Mg}(\mathrm{OH})_{2}\right]$, aluminium hydroxide $\left[\mathrm{Al}(\mathrm{OH})_{3}\right]$ and titanium dioxide $\left(\mathrm{TiO}_{2}\right)$. Six samples were prepared in this research, whereby two samples contain only single filler (i.e. $\mathrm{POC}, \mathrm{TiO}_{2}$ ) and four samples contain hybrid fillers. The compositions of the intumescent coatings prepared in this study are presented in Table 1. The intumescent coatings were blended using a high-speed disperse mixer for $\sim 2-3 \mathrm{~h}$ until the coatings were completely homogenous. Each coating was applied onto one side of the steel plate using a spray gun up to a dry film thickness of $1.5 \pm 0.2 \mathrm{~mm}$. The intumescent coatings were characterized once the coatings were fully dried.

\section{BUNSEN BURNER TEST}

Bunsen burner test was carried out to characterize the char formation and determine the temperature development for each specimen. The specimen was mounted vertically and exposed to high temperature of $\sim 1000^{\circ} \mathrm{C}$ for $1 \mathrm{~h}$ using the Bunsen burner. A thermocouple wire was attached to the back side of the steel plate to measure the temperature during the Bunsen burner test. The thermocouple was connected to a digital thermometer in order to record the temperature measurements. The temperature was recorded in $1 \mathrm{~min}$ intervals until the steel plate reached its critical

TABLE 1. Compositions of the intumescent coatings

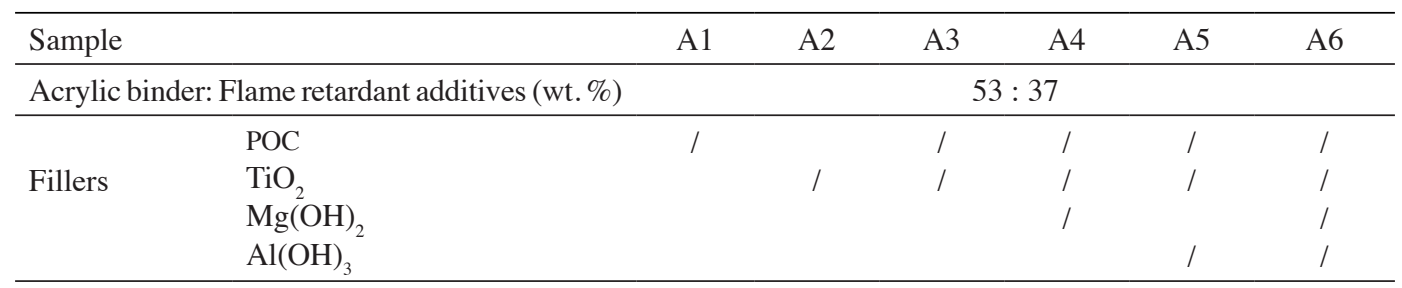

wt. $\%$ = weight percent, APP: ammonium polyphosphate; MEL: melamine; PER: pentaerythritol; POC: palm oil clinker; $\mathrm{Mg}(\mathrm{OH})_{2}: \operatorname{magnesium}$ hydroxide; $\mathrm{Al}(\mathrm{OH})_{3}$ : aluminium hydroxide; $\mathrm{TiO}_{2}$ : titanium dioxide 
temperature. A temperature of $400^{\circ} \mathrm{C}$ was chosen as the failure temperature for the steel structure to ensure a higher level of safety and protection (Yew \& Sulong 2011).

\section{THERMOGRAVIMETRIC ANALYSIS}

TGA was carried out using a thermogravimetric analyser (Model: TGA/SDTA851e) within a temperature range of 30$1000^{\circ} \mathrm{C}$ at a heating rate of $20^{\circ} \mathrm{C} / \mathrm{min}$ under airflow. TGA was used to measure the weight change of the coating as a function of temperature when the coating was heated at a constant heating rate.

\section{SURFACE SPREAD OF FLAME TEST}

The surface spread of flame test was performed in accordance with the BS 476: Part 7 standard. The test was carried out on the samples with the best fire protection performance. The test specimen was oriented in a vertical position and the lateral spread of flame over the surface was measured. The sample was then classified based on the rate and extent of flame spread. The steel plate $(885$ $\mathrm{mm} \times 270 \mathrm{~mm} \times 2.3 \mathrm{~mm}$ ) coated with the best formulation of intumescent coating (film thickness: $1.5 \pm 0.2 \mathrm{~mm}$ ) was exposed to specific heating conditions during the test. The test specimen was mounted vertically and placed at an angle of $90^{\circ}$ from the radiation panel and was exposed to the radiation panel for $10 \mathrm{~min}$. The pilot flame was applied to the bottom corner of the specimen during the first minute of the test. The time required for the flame front to reach the reference marks on the specimen and the extent of flame spread were recorded over a period of $1.5 \mathrm{~min}$ as well as at the end of the test. The intumescent coating was classified according to the rate and extent of flame spread, as shown in Table 2. Class 1 is the best classification whereas Class 4 is the worst classification. If the coating falls under Class 4 , this means that the coating is at a high risk.

\section{FIELD EMISSION SCANNING ELECTRON MICROSCOPY}

After the Bunsen burner test, a piece of char was cut from the centre of the char layer in order to examine its surface morphology using FESEM. Field emission scanning electron microscope (Model: GEMINI ${ }^{\circledR}$, Carl Zeiss AG, Germany), with a low beam energy of $1 \mathrm{kV}$ was used to observe the morphology of the char layer.

\section{STATIC IMMERSION TEST}

Static immersion test was used to evaluate the water resistance of thin films. The intumescent coatings were immersed in distilled water at $25^{\circ} \mathrm{C}$ and then dried with a piece of paper towel to remove excess water. The weight change of the samples was recorded and this step was repeated at a specific time interval. The weight change of the samples was calculated using (1).

$$
\Delta W=\frac{W_{e}-W_{o}}{W_{o}} \times 100 \%
$$

where $\Delta W$ is the water intake ratio of the film; $W_{e}$ is the weight of the film after water immersion; and $W_{o}^{e}$ is the weight of the film before water immersion.

\section{ADHESION STRENGTH TEST}

The adhesion strength at the interface of the intumescent coating and steel substrate was determined using a pulloff adhesion tester (PosiTest-AT-A Automatic, DeFelsko). The coating was applied onto one side of a steel plate (dimensions: $50 \times 50 \times 2.6 \mathrm{~mm}$ ) to obtain a film thickness of $0.5 \pm 0.05 \mathrm{~mm}$. The flat face of a pull stub (20 mm dolly) was adhered to the coating using epoxy glue (thickness: $0.5 \pm 0.05 \mathrm{~mm}$ ). The force of the peeled-off area for the samples was calculated and classified according to the ASTM D4541 standard. The bonding strength $f_{b}$ was calculated using (2):

$$
f_{b}=F / A
$$

where $F$ is the crack charge and $A$ is the sticking area.

\section{RESULTS AND DISCUSSION}

\section{THERMAL DEGRADATION OF POC}

Figure 1 shows the TGA curve of the POC. It can be seen that the weight loss of the POC is only about $2 \%$ at a temperature of $500^{\circ} \mathrm{C}$. The high thermal stability of this filler is attributed to the process of incinerating oil palm shells and palm oil fibres at $850^{\circ} \mathrm{C}$ for power generation. It can be deduced that the incorporation of POC as a bio-filler in the intumescent coating will enhance fire retardancy of the coating due to its high thermal stability.

TABLE 2. Classification of flame spread

\begin{tabular}{lcccc}
\hline Classification & \multicolumn{2}{c}{ Spread of flame at 1.5 min } & \multicolumn{2}{c}{ Final spread of flame (10 min) } \\
\cline { 2 - 5 } & $\begin{array}{c}\text { Limit } \\
(\mathrm{mm})\end{array}$ & $\begin{array}{c}\text { Tolerance for one specimen } \\
\text { in sample } \\
(\mathrm{mm})\end{array}$ & $\begin{array}{c}\text { Limit } \\
(\mathrm{mm})\end{array}$ & $\begin{array}{c}\text { Tolerance for one specimen } \\
\text { in sample } \\
(\mathrm{mm})\end{array}$ \\
\hline Class 1 & 165 & 25 & 165 & 25 \\
Class 2 & 215 & 25 & 455 & 45 \\
Class 3 & 265 & 25 & 710 & 75 \\
Class 4 & & Exceeding the limits for class 3 & \\
\hline
\end{tabular}




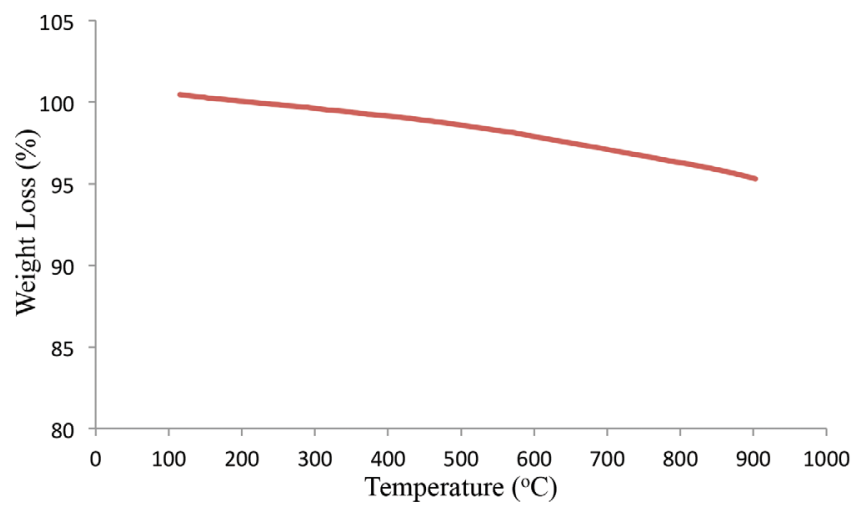

FIGURE 1. TGA curve of the POC

\section{FIRE PERFORMANCE TEST}

Figure 2 shows the time-temperature curves for all intumescent coatings investigated in this research. The results show that the temperature increases rapidly during the first 5 to $10 \mathrm{~min}$ for all coatings. It can be seen that the temperature for Sample A2 increases rapidly after $\sim 30 \mathrm{~min}$ of the Bunsen burner test since the char falls off from the steel plate which leads to failure of the sample. It is likely that the char layer is unable to adhere to the steel plate because of its lightness or due to a loss of cohesion of the char because of physical and chemical reactions that take place during the test (Yew et al. 2015). After $30 \mathrm{~min}$, the temperature of all coatings reaches an equilibrium value, whereby the temperature is almost invariant with respect to time. The equilibrium temperature and thickness of the char layer for all samples are summarized in Table 3. Sample A1 (with only POC) has better fire protection performance compared with Sample A2. Sample A6 (hybrid filler formulation) offers the best fire protection with the lowest equilibrium temperature $\left(171.3^{\circ} \mathrm{C}\right)$ and highest char layer thickness $(29.1 \mathrm{~mm})$. The results indicate

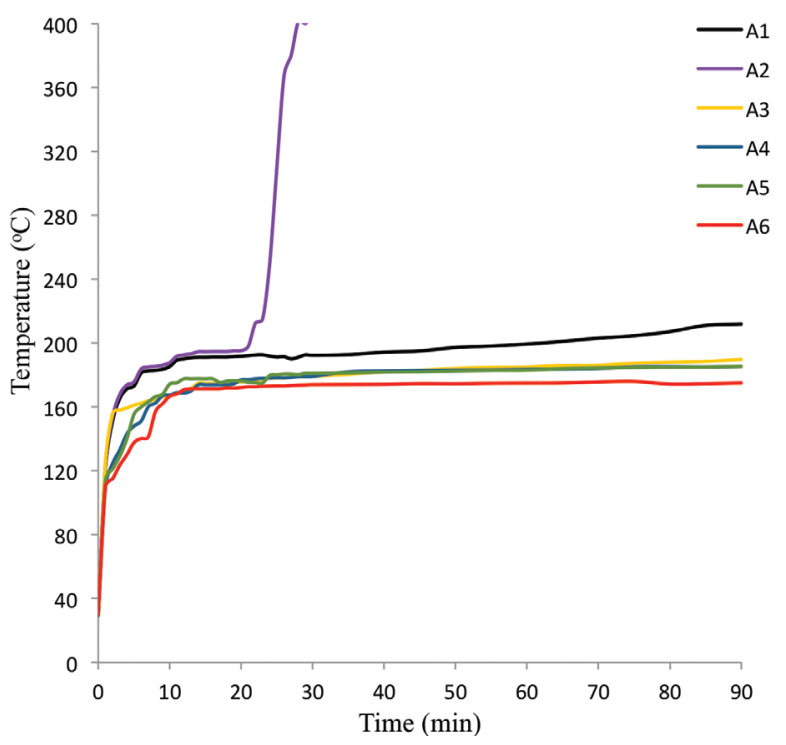

FIGURE 2. Time-temperature curves of intumescent coatings
TABLE 3. Char layer thickness and equilibrium temperature of intumescent coatings

\begin{tabular}{ccc}
\hline Coating & $\begin{array}{c}\text { Equilibrium temperature } \\
\left({ }^{\circ} \mathrm{C}\right)\end{array}$ & $\begin{array}{c}\text { Char thickness } \\
(\mathrm{mm})\end{array}$ \\
\hline A1 & 191.1 & 21.81 \\
A2 & - & - \\
A3 & 174.8 & 26.27 \\
A4 & 173.8 & 27.20 \\
A5 & 177.6 & 24.47 \\
A6 & 171.3 & 29.10 \\
\hline
\end{tabular}

that the optimum combination of POC and hybrid fillers is highly effective to enhance the fire protection performance of intumescent coatings.

\section{THERMAL ANAYSIS OF INTUMESCENT COATINGS}

Figure 3 shows the TGA curves of the intumescent coatings. It can be observed that all of the coatings show a similar trend between 100 and $250^{\circ} \mathrm{C}$. However, the TGA curve differs slightly from one another at $400^{\circ} \mathrm{C}$. The residual weight of Sample A1, A2, A3, A4, A5, and A6 at $750^{\circ} \mathrm{C}$ is $25.2,15.0,26.7,27.7,24.5$ and $32 \mathrm{wt}$ \%, respectively. Sample A2 (without POC) has the lowest residual weight, with a value of $15 \mathrm{wt}$ \%. Sample A1 (with only POC) has higher thermal stability, which is indicated by the increase in residual weight by $10.2 \mathrm{wt}$ \%. More importantly, it can be seen that the addition of hybrid fillers increases the thermal stability of the intumescent coating up to $32 \mathrm{wt}$. $\%$, as evidenced from Sample A6. By comparing Sample A4 with Sample A5, it can be seen that the incorporation of $\mathrm{Mg}(\mathrm{OH})_{2}$ improves the thermal stability of the coating with an increase in the residual weight of $3.2 \mathrm{wt}$. \%. This may be attributed to the endothermic decomposition of $\mathrm{Mg}(\mathrm{OH})_{2}$ filler which forms a gaseous water phase. It is believed that this gaseous water phase engulfs the flame, blocking oxygen and diluting the flammable gases (Hornsby \& Watson 1990). Sample A6 has the highest thermal stability, which clearly indicates that the combination of POC and suitable amount of hybrid fillers improves anti-oxidation, thermal stability and fire protection performance of the 
intumescent coating (Yew et al. 2014). It can be deduced that the intumescent coating has superior fire protection performance with the incorporation of hybrid fillers, whereby POC is one of the key components.

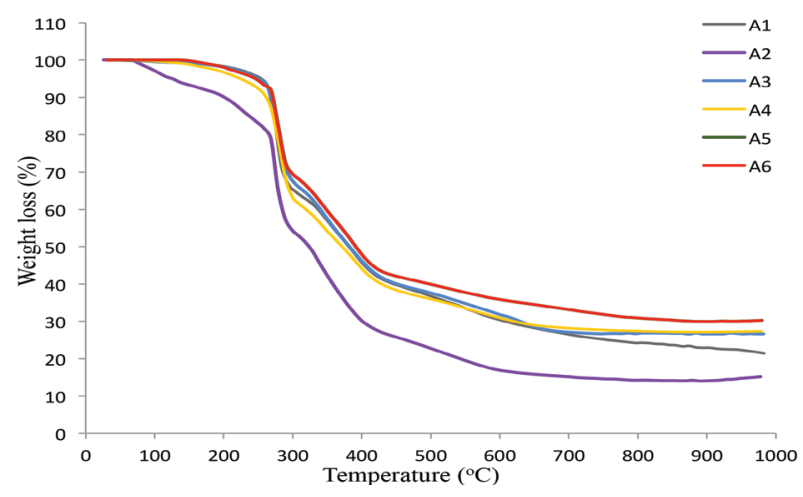

FIGURE 3. TGA curves of intumescent coatings

\section{SURFACE SPREAD OF FLAME TEST}

Three samples with the best fire protection performance (i.e. Sample A3, A4, and A6) were selected for the surface spread of flame test in order to measure the rate and extent of the flame spread and the results are tabulated in Table 4. The surface spread of flame test was performed according to the procedure outlined in the BS 476: Part 7 standard. The test specimen was oriented in a vertical position and the lateral spread of flame over the surface was measured. The sample was then classified based on the rate and extent of flame spread. Class 1 is the best classification whereas Class 4 is the worst classification where the sample is at high risk. In this research, all of the samples are classified under Class 1 since the final spread of flame is less than $190 \mathrm{~mm}$. The surface spread of flame is $190 \mathrm{~mm}$ for Sample A3 and A4 at 51 and 60 $\mathrm{s}$, respectively. In contrast, the surface spread of flame is $0 \mathrm{~mm}$ for Sample A6, which attests that the optimum composition of POC and hybrid filler significantly lowers the rate and extent of flame spread.

\section{MORPHOLOGY OF INTUMESCENT CHAR LAYERS}

The physical structure of the char layer has a significant effect on the fire protection performance of intumescent coatings (Wang et al. 2006). Figure 4 shows the surface morphology of the char layer for all samples. It can be observed that Sample A1, A2 and A5 have a highly porous surface structure, which reduces the fire protection capability of the coatings. This is indeed expected since the heat penetrates to the steel substrate through the char layer since the char layer is highly porous and non-uniform. In contrast, the char layer for Sample A3, A4 and A6 is more uniform with a dense foam structure which prevents heat from penetrating through the steel substrate. This enhances the fire protection performance of the coatings. This shows that the incorporation of POC and other fireretardant fillers allow the binder to mix well, resulting in a more homogeneous coating with better interfacial bonding of the filler/matrix components.

TABLE 4. Results of the surface spread of flame test

\begin{tabular}{|c|c|c|c|}
\hline Specimen No. & A3 & A4 & A6 \\
\hline Spread of flame at $11 / 2 \mathrm{~min}(\mathrm{~mm})$ & 190 & 190 & 0 \\
\hline Distance (mm) & \multicolumn{3}{|c|}{ Time of spread of flame to indicated distance (min.s) } \\
\hline 75 & 0.27 & 0.47 & \\
\hline 165 & 0.35 & 0.58 & \\
\hline 190 & 0.51 & 1.00 & \\
\hline \multicolumn{4}{|l|}{215} \\
\hline \multicolumn{4}{|l|}{240} \\
\hline \multicolumn{4}{|l|}{265} \\
\hline \multicolumn{4}{|l|}{290} \\
\hline \multicolumn{4}{|l|}{375} \\
\hline \multicolumn{4}{|l|}{455} \\
\hline \multicolumn{4}{|l|}{500} \\
\hline \multicolumn{4}{|l|}{525} \\
\hline \multicolumn{4}{|l|}{600} \\
\hline \multicolumn{4}{|l|}{675} \\
\hline \multicolumn{4}{|l|}{710} \\
\hline \multicolumn{4}{|l|}{750} \\
\hline \multicolumn{4}{|l|}{785} \\
\hline \multicolumn{4}{|l|}{825} \\
\hline \multicolumn{4}{|l|}{865} \\
\hline Time of maximum spread of flame (min.s) & 0.51 & 1.00 & - \\
\hline Distance of maximum spread of flame (mm) & 190 & 190 & 0 \\
\hline Classification & Class-1 & Class-1 & Class-1 \\
\hline
\end{tabular}



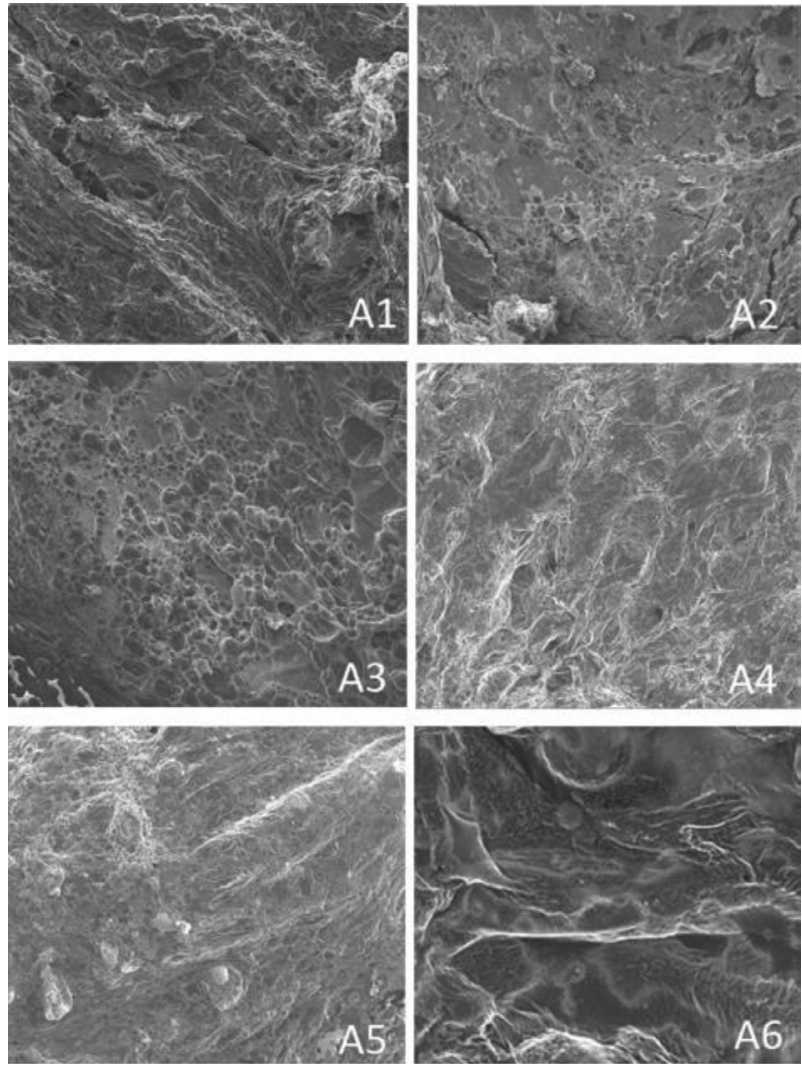

FIGURE 4. Structure of the char layer of intumescent coatings

\section{STATIC IMMERSION TEST}

Figure 5 shows the rate of weight change curves for all coatings studied in this research. It can be observed that the weight of Sample A1 and A3 decreases gradually due to the permeation process. This means that water can infiltrate into the porous structure of the coatings, which leads to weight gain of these samples. The weight gain is also due to the solubility of POC in water. This indicates that intumescent coatings with POC can be used for internal use since it can absorb water. In contrast, there is a weight loss for Sample A2, A4, and A6 due to the migration process. According to Yeh et al. (2006), the migration process may occur when some hydrophilic fire-retardant additives dissolve in water during the migration process, which will reduce the weight of the intumescent coating. It seems that both migration and permeation processes occur for Sample A5 which contains $\mathrm{Al}(\mathrm{OH})_{3}$ filler. The permeation of water and dissolution of the fire-retardant components can be slowed down by the addition of $\mathrm{Al}(\mathrm{OH})_{3}$ filler due to its low solubility in water, which improves the water resistance of the intumescent coating (Harlan Laboratories 2010). In general, the rate of weight change is less than $0.5 \%$ for all samples, indicating that the samples have excellent water resistance.

\section{ADHESION STRENGTH TEST}

The adhesion strength of the intumescent coatings investigated in this study is presented in Table 5. It can

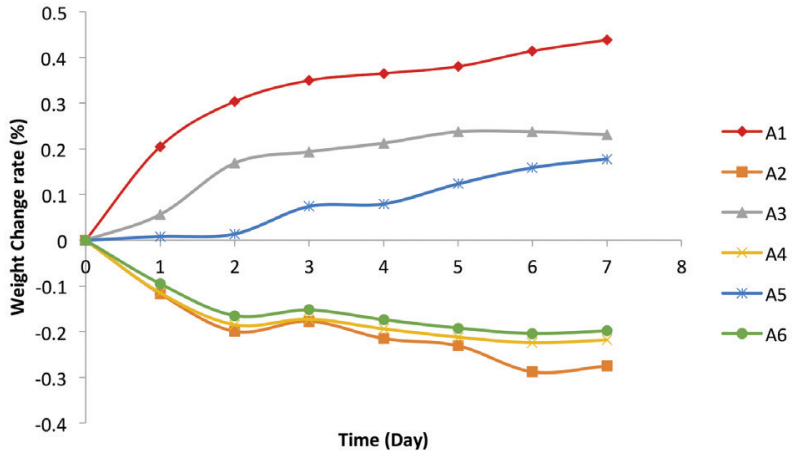

FIGURE 5. Rate of weight change curves of intumescent coatings

be seen that Sample A1 has higher adhesion strength compared with Sample A2, which indicates that the POC bio-filler slightly increases the adhesion strength of the intumescent coating. However, there is a significant enhancement in the adhesion strength for hybrid filler formulations, which is evident for Sample A4 and A6. The addition of $\mathrm{Mg}(\mathrm{OH})_{2}$ filler into Sample A4 results in a strong bonding strength between the steel surface and coating layer. Sample A6 has the highest adhesion strength since this coating has the optimum combination of POC, $\mathrm{Mg}(\mathrm{OH})_{2} \mathrm{TiO}_{2}$ and $\mathrm{Al}(\mathrm{OH})_{3}$ fillers, as expected. In general, the addition of $\mathrm{POC}$ and $\mathrm{Mg}(\mathrm{OH})_{2}$, fillers enhances the adhesion strength of the intumescent coating, while the optimum combination of hybrid fillers will significantly boost the adhesion strength of the intumescent coating.

TABLE 5. Adhesion strength of intumescent coatings

\begin{tabular}{ccc}
\hline Coating & $\begin{array}{c}\text { Crack charge, } \\
\mathrm{F}(\mathrm{N})\end{array}$ & $\begin{array}{c}\text { Adhesion strength, } \\
\text { fb (MPa) }\end{array}$ \\
\hline $\mathrm{A} 1$ & 810 & 2.58 \\
$\mathrm{~A} 2$ & 603 & 1.92 \\
$\mathrm{~A} 3$ & 1492 & 4.75 \\
$\mathrm{~A} 4$ & 1608 & 5.12 \\
$\mathrm{~A} 5$ & 967 & 3.08 \\
$\mathrm{~A} 6$ & 1825 & 5.81 \\
\hline
\end{tabular}

\section{CONCLUSION}

This research is focused on investigating the fire protection performance of different formulations of intumescent coatings, incorporating $\mathrm{POC}$ as bio-filler and hybrid fillers. Based on the results of the Bunsen burner test, it is found that Sample A1 (with only POC) provides good fire protection. However, Sample A6 (with composition of POC and suitable amount of hybrid fillers) gives the best fire protection performance with the lowest equilibrium temperature and highest char layer thickness. This indicates that the mixture of POC and hybrid fillers is more effective in enhancing the fire protection of intumescent coatings. Based on the TGA results, the temperature difference 
between Sample A1 and Sample A6 is 7\%, indicating that the addition of hybrid fillers provides excellent thermal stability. Based on the results of the surface spread of flame test, Sample A3, A4 and A6 fall under Class 1 since the final spread of flame is less than $190 \mathrm{~mm}$. The surface spread of flame for Sample A6 is $0 \mathrm{~mm}$, indicating that the composition of POC and suitable amount of hybrid fillers significantly lowers the rate and extent of the flame spread over the surface. The combination of POC and $\mathrm{Al}(\mathrm{OH})_{3}$ fillers slows down the permeation of water and dissolution of fire-retardant components due to the low solubility of $\mathrm{Al}(\mathrm{OH})_{3}$ in water, which improves the water resistance of the coatings. Sample A4 has a higher adhesion strength owing to the addition of $\mathrm{Mg}(\mathrm{OH})_{2}$ filler, which improves interfacial adhesion between the steel surface and coating layer. In general, it can be concluded that the optimum composition of hybrid fillers (with POC as one of the key components) results in the best fire protection performance, high water resistance, and excellent adhesion strength for the intumescent coatings.

\section{ACKNOWLEDGEMENTS}

This work was supported by the Ministry of Education (MoE), Malaysia under FRGS Grant FP047-2013B and University of Malaya under PPP grant PG139-2016A.

\section{REFERENCES}

Ahmmad, R., Jumaat, M.Z., Alengaram, U.J., Bahri, S., Rehman, M.A. \& Hashim, H. 2016. Performance evaluation of palm oil clinker as coarse aggregate in high strength lightweight concrete. Journal of Cleaner Production 112(Part 1): 566574.

Bodzay, B., Bocz, K., Barkai, Z. \& Marosi, G. 2011. Influence of rheological additives on char formation and fire resistance of intumescent coatings. Polymer Degradation and Stability 96(3): 355-362.

Dai, X.H., Wang, Y.C. \& Bailey, C.G. 2009. Effects of partial fire protection on temperature developments in steel joints protected by intumescent coating. Fire Safety Journal 44(3): 376-386.

Duquesne, S., Magnet, S., Jama, C. \& Delobel, R. 2004. Intumescent paints: Fire protective coatings for metallic substrates. Surface \& Coatings Technology 180: 302-307.

Duquesne, S., Magnet, S., Jama, C. \& Delobel, R. 2005. Thermoplastic resins for thin film intumescent coatings towards a better understanding of their effect on intumescence efficiency. Polymer Degradation and Stability 88(1): 63-69.

Enescu, D., Frache, A., Lavaselli, M., Monticelli, O. \& Marino, F. 2013. Novel phosphorous-nitrogen intumescent flame retardant system. Its effects on flame retardancy and thermal properties of polypropylene. Polymer Degradation and Stability 98(1): 297-305.

Harlan Laboratories Ltd. UK. 2010. Aluminium Hydroxide. Determination of Water Solubility. Project No.: 2962/0003. UK. A Study Conducted at the Request of the Aluminium REACH Consortium.

Hornsby, P.R. \& Watson, C.L. 1990. A study of the mechanism of flame retardance and smoke suppression in polymers filled with magnesium hydroxide. Polymer Degradation and Stability 30(1): 73-87.

Jimenez,M.,Duquesne, S.\& Bourbigot, S. 2006a. Characterization of the performance of an intumescent fire protective coating. Surface \& Coatings Technology 201(3-4): 979-987.

Jimenez, M., Duquesne, S. \& Bourbigot, S. 2006b. Intumescent fire protective coating: Toward a better understanding of their mechanism of action. Thermochimica Acta 449(1-2): 16-26.

Jumaat, M.Z., Alengaram, U.J., Ahmmad, R., Bahri, S. \& Islam, A.B.M.S. 2015. Characteristics of palm oil clinker as replacement for oil palm shell in lightweight concrete subjected to elevated temperature. Construction and Building Materials 101: 942-951.

Liang, S.Y., Neisius, N.M. \& Gaan, S. 2013. Recent developments in flame retardant polymeric coatings. Progress in Organic Coatings 76(11): 1642-1665.

Norgaard, K.P., Dam-Johansen, K., Catala, P. \& Kiil, S. 2013. Investigation of char strength and expansion properties of an intumescent coating exposed to rapid heating rates. Progress in Organic Coatings 76(12): 1851-1857.

Pan, L.L., Li, G.Y., Su, Y.C. \& Lian, J.S. 2012. Fire retardant mechanism analysis between ammonium polyphosphate and triphenyl phosphate in unsaturated polyester resin. Polymer Degradation and Stability 97(9): 1801-1806.

Price, D., Pyrah, K., Hull, T.R., Milnes, G.J., Ebdon, J.R., Hunt, B.J. \& Joseph, P. 2002. Flame retardance of poly(methyl methacrylate) modified with phosphorus-containing compounds. Polymer Degradation and Stability 77(2): 227-233.

Wang, G.J. \& Yang, J.Y. 2010. Influences of binder on fire protection and anticorrosion properties of intumescent fire resistive coating for steel structure. Surface \& Coatings Technology 204(8): 1186-1192.

Wang,Z.Y., Han, E.H. \& Ke, W. 2006. Effect of nanoparticles on the improvement in fire-resistant and anti-ageing properties of flame-retardant coating. Surface \& Coatings Technology 200(20-21): 5706-5716.

Yeh, J.M., Huang, H.Y., Chen, C.L., Su, W.F. \& Yu, Y.H. 2006. Siloxane-modified epoxy resin-clay nanocomposite coatings with advanced anticorrosive properties prepared by a solution dispersion approach. Surface \& Coatings Technology 200(8): 2753-2763.

Yew, M.C. 2011. Investigation on water-borne intumescent fire protective coatings for steel. Master Thesis. University of Malaya, Kuala Lumpur, Malaysia (Unpublished).

Yew, M.C. \& Sulong, N.H.R. 2012. Fire-resistive performance of intumescent flame-retardant coatings for steel. Materials Design 34: 719-724.

Yew, M.C. \& Ramli Sulong, N.H. 2011. Effect of epoxy binder on fire protection and bonding strength of intumescent fire protective coating for steel. Advanced Materials Research 168-170: 1228-1232.

Yew, M.C., Sulong, N.H.R., Yew, M.K., Amalina, M.A. \& Johan, M.R. 2015. Influences of flame-retardant fillers on fire protection and mechanical properties of intumescent coatings. Progress in Organic Coatings 78: 59-66.

Yew, M.C., Sulong, N.H.R., Yew, M.K.,Amalina, M.A. \& Johan, M.R. 2014. Investigation on solvent-borne intumescent flame-retardant coatings for steel. Materials Research Innovations 18: 384-388.

Yew, M.C., Sulong, N.H.R., Yew, M.K.,Amalina, M.A. \& Johan, M.R. 2013. The formulation and study of the thermal stability 
and mechanical properties of an acrylic coating using chicken eggshell as a novel bio-filler. Progress in Organic Coatings 76(11): 1549-1555.

Department of Civil Engineering

Faculty of Engineering

University of Malaya, Lembah Pantai

50603 Kuala Lumpur, Federal Territory

Malaysia
*Corresponding author; email: hafizah_ramli@um.edu.my

Received: 24 January 2017

Accepted: 8 June 2017 